American Journal of Biochemistry and Biotechnology 2 (4): 186-194, 2006

ISSN 1553-3468

(C) 2006 Science Publications

\title{
Optimum Conditions for Measuring Dehydrogenase Activity of Aspergillus niger using TTC
}

\author{
A. E. Ghaly and N. S. Mahmoud \\ Department of Process Engineering and Applied Science,Dalhousie University \\ Halifax, Nova Scotia, Canada B3J 2X4
}

\begin{abstract}
The suitability of the triphenyl tetrazolium chloride (TTC) for dehydrogenase activity measurement of the vegetative cells of the fungal species Aspergillus niger was investigated. The triphenyl formazan (TF) yield increased with the increases in TTC concentration, $\mathrm{pH}$, temperature and incubation time within the studied ranges. The effects of individual parameters, as well as the combined effects, on the TF yield were found to follow exponential expressions. The sensitivity analysis showed that the TF yield is more sensitive to changes in temperature followed by $\mathrm{pH}$, TTC concentration and incubation time. Although the rate of increase in the enzyme activity decreased gradually with the increase in temperature, no enzyme denaturation was observer below $55{ }^{\circ} \mathrm{C}$. The optimum TTC-test conditions for measuring the dehydrogenase activity of $A$. niger vegetative cells are a TTC concentration of $15 \mathrm{~g} / \mathrm{L}$, a pH of 9 , a temperature of $55^{\circ} \mathrm{C}$ and an incubation time of $4 \mathrm{~h}$. Although the procedure has been successfully tested with mycelia of different stages of growth, it would be interesting to test the effects of different stages of growth on TTC reduction under both aerobic and anaerobic conditions.
\end{abstract}

Keywords: Dehydrogenase activity, Aspergillus niger, triphenyl tetrazolium chloride, triphenyl formazan, TTC concentration, $\mathrm{pH}$, temperature, incubation time.

\section{INTRODUCTION}

Aspergillus niger is a filamentous fungi capable of producing organic acids ${ }^{[1-3]}$ (citric and gluconic acids) and several enzymes that can be used in different industrial applications. Pandey ${ }^{[4]}$ reported that $A$. niger can produce more than 19 types of enzymes including alpha amylase, beta amylase, maltase, lactase, catalase, proteinase, trehalase, tannase, dipetalase, polypetalase, lipase, cellulase, amidase, glucose oxidase, glucose dihydrogenase, urease, insulase, melibase and zymase. $A$. niger species contain chitin in their cell wall (about $42.0 \%$ of the dry weight of the cell wall), which is a versatile environmentally friendly biopolymer ${ }^{[5,6]}$.

Hesseltine ${ }^{[7]}$ stated that $A$. niger species are often most suited to solid state fermentation for the production of industrially important products because their growth conditions are similar to those of the natural habitats. During solid state fermentation, the fungus is intimately bound to the solid matrix ${ }^{[8]}$. Continuous biomass quantification for monitoring and control of bioreactors using the traditional methods (such as gravimetric methods, direct microscopic count, plate count, measuring the change in optical density, and determination of cell constitutes) is very difficult. Methods that are based on measuring the dehydrogenase activity (using a dye as an electron acceptor) seem to be less costly, simple, fast and suitable for biomass estimation during solid state fermentation.

Dehydrogenase activity is caused by a wide group of endocellular enzymes, which are present in all living cells and are essential in catalyzing the biological oxidation of organic compounds. They transfer hydrogen and electrons through a chain of intermediate electron carriers to oxygen as a final electron acceptor, which then combine with them and form water ${ }^{[9-11]}$. The triphenyltetrazolium chloride (TTC) is a stable, water soluble heterocyclic organic salt that can be easily reduced to form a highly colored insoluble product (red formazan), which can be quantified colorimetrically by visible light absorption. TTC has been widely used as a direct measurement of microbial growth ${ }^{[12-16]}$. Equations (1) and (2) describe the two step reaction of $\left.\mathrm{TTC}^{[17}\right]$ :

(a) Biological oxidation of organic compounds:

$\mathrm{RH}_{2} \stackrel{\text { Dehydrogenase }}{\longrightarrow} \mathrm{R}+2 \mathrm{H}^{+}+2 \mathrm{e}^{-}$

(b) Chemical reduction of tetrazolium salts:

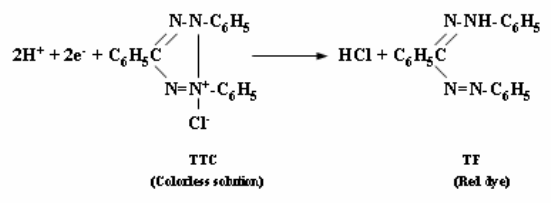

Corresponding Author: A. E. Ghaly, Process Engineering and Applied Science Department, Dalhousie University, Halifax, Nova Scotia, Canada B3J 2X4, Tel: (902)494-6014, Fax: (902)423-2423. 
Although measuring the dehydrogenase activity using the TTC test depends on the biochemical reduction of the TTC, we have observed a chemical reduction of TTC at high temperature and $\mathrm{pH}$ values ${ }^{[18]}$. In addition, the medium $\mathrm{pH}$, incubation temperature, quantity of tetrazolium salt and incubation period are critical parameters that affect the accuracy of dehydrogenase activity measurements using tetrazolium salts.

\section{OBJECTIVES}

The objectives of this study were to: (a) investigate the applicability of the TTC-test for quantifying the growth of the fungal species Aspergillus niger and (b) determine the optimum TTC test conditions $(\mathrm{pH}$, temperature, TTC concentration and incubation time).

\section{EXPERIMENTAL MATERIALS}

\section{Microorganisms}

Aspergillus niger (ATCC 6275) was obtained from the American Type Culture Collection (Rockville, Maryland) as freeze dried culture. The freeze dried culture was revived in $6 \mathrm{~mL}$ of $0.1 \%$ sterilized peptone solution, which was prepared by dissolving $1 \mathrm{~g}$ Bactopeptone (Difco, Detroit, Michigan, USA) in $1 \mathrm{~L}$ deionized-distilled water and then sterilized in an autoclave (Model No. STM-E, Market Forge Sterilmatic, New York) at $121{ }^{\circ} \mathrm{C}$ and $103.4 \mathrm{kPa}$ for 30 minutes. The rehydrated culture was kept in the peptone solution in caped test tubes for 24 hours at room temperature $\left(24^{\circ} \mathrm{C}\right)$. One $\mathrm{mL}$ each of the rehydrated $A$. niger was transferred to a test tube containing $9 \mathrm{~mL}$ potato dextrose broth (PDB), which contained infusion from $200 \mathrm{~g}$ potatoes $(4 \mathrm{~g} / \mathrm{L})$ and $20 \mathrm{~g} / \mathrm{L}$ Bacto dextrose. The test tubes were kept tight caped for $48 \mathrm{~h}$ at room temperature $\left(24^{\circ} \mathrm{C}\right)$. A spore stock suspension was then obtained by growing the fungus on potato dextrose agar (PDA), which contained infusion from $200 \mathrm{~g}$ potatoes $(4 \mathrm{~g} / \mathrm{L}), 20 \mathrm{~g} / \mathrm{L}$ Bacto dextrose and $15 \mathrm{~g} / \mathrm{L}$ Bacto agar, at room temperature $\left(24{ }^{\circ} \mathrm{C}\right)$ for 4 days. The conidia were harvested from the surface by adding sterilized deionized distilled water containing $0.01 \%(\mathrm{v} / \mathrm{v})$ Tween 80 and scraping the surface with a sterilized spatula. The spore concentration was determined using direct standard plate count method according to the procedures described in the Standard Method for the Examination of Dairy Products ${ }^{[19]}$. The prepared suspension was stored in the refrigerator at about $4{ }^{\circ} \mathrm{C}$ until needed. A fresh suspension was prepared on a weekly basis when needed.

\section{Reagents}

The chemicals used in performing the dehydrogenase activity tests included: $0.05 \mathrm{M}$ tris (hydroxymethyl) aminomethane hydrochloride $\left(\mathrm{NH}_{2} \mathrm{C}\left[\mathrm{CH}_{2} \mathrm{OH}\right]_{3} \cdot \mathrm{HCl}\right)$ buffer solution ( $\mathrm{pH} \sim 8.0$ ), glucose and 2:3:5 triphenyl tetrazolium chloride salt (TTC). The tris buffer was used to control the $\mathrm{pH}$ of the samples. The $0.05 \mathrm{M}$ buffer was prepared by dissolving $6.057 \mathrm{~g}$ tris (hydroxymethyl) aminomethane $\left(\mathrm{C}_{4} \mathrm{H}_{11} \mathrm{NO}_{3}\right)$ in $20 \mathrm{~mL}$ $1.0 \mathrm{~N} \mathrm{HCl}$ and bringing the solution to $1.0 \mathrm{~L}$ with distilled-deionized water. The glucose served as an immediately-bioavailable carbon supply to enhance the ability of microorganisms to reduce the TTC within the incubation period ${ }^{[20]}$. The TTC/glucose solutions were prepared by adding either $0.50,1.0,1.5 \mathrm{~g}$ triphenyl tetrazolium chloride $\left(\mathrm{C}_{19} \mathrm{H}_{15} \mathrm{~N}_{4} \mathrm{Cl}\right)$ depending on the required concentration and $1 \mathrm{~g}$ glucose $\left(\mathrm{CH}_{2} \mathrm{OH}[\mathrm{CHOH}]_{4} \mathrm{CHO}\right)$ to a $100 \mathrm{~mL}$ volumetric flasks and bringing the solution to $100 \mathrm{~mL}$ with distilleddeionized water. The TTC solution is sensitive to light and was, therefore, kept in the dark at near $0{ }^{\circ} \mathrm{C}$. Solutions over one week old were discarded.

\section{EXPERIMENTAL PROCEDURE}

\section{TTC Standard Curve}

In order to determine the formazan concentration $\left(\mathrm{C}_{\mathrm{TF}}\right)$ produced from the reduction of triphenyl tetrazolium chloride (TTC), a standard curve was developed from solutions of triphenyl formazan and ethyl alcohol with different concentrations. First, a standard solution of $0.0002 \quad \mathrm{M}$ triphenyl formazan $\left(\mathrm{C}_{6} \mathrm{H}_{5} \mathrm{~N}: \mathrm{NC}\left[\mathrm{C}_{6} \mathrm{H}_{5}\right]: \mathrm{NNHC}_{6} \mathrm{H}_{5}\right)$ was prepared by dissolving $0.03 \mathrm{~g}$ triphenyl formazan in $500 \mathrm{~mL}$ ethyl alcohol. Then, a set of 9 solutions with triphenyl formazan concentrations of 1.2, 3.0, 6.0, 9.0, 12.0, 15.0, $18.0,21.0$ and $24.0 \mu \mathrm{g} / \mathrm{mL}(0.2,0.5,1.0,1.5,2.0,2.5$, $3.0,3.5$, and $4.0 \mu \mathrm{mol} / 50 \mathrm{~mL}$ ) were prepared. Finally, the optical densities of the prepared solutions were measured (in duplicates) using spectrophotometer (Spectronic 601, Fisher Scientific, Montreal, Quebec, Canada) at a wavelength of $484 \mathrm{~nm}$ and plotted against the known TF concentrations $(\mu \mathrm{mol} / \mathrm{mL})$ as shown in Figure 1. A blank sample was used to zero the spectrophotometer.

\section{Experimental Design}

Four factors (TTC concentration, $\mathrm{pH}$, temperature and incubation time) with three levels each $(5,10$ and 15 $\mathrm{g} / \mathrm{L}$ for TTC concentration, 7,8 and 9 for $\mathrm{pH}, 25,40$ and $55{ }^{\circ} \mathrm{C}$ for temperature and $1.5,3$ and $4.5 \mathrm{~h}$ for incubation period) were investigated. The experiment was designed as $3^{4}$ factorial with two replicates. This resulted in 162 runs. The TF yield was determined for each experimental run.

\section{Sample Preparation}

Samples were prepared in test tubes by inoculating 4.7 $\mathrm{mL}$ potato dextrose broth with $0.3 \mathrm{~mL}$ of spores $(70 \times$ $10^{6} \mathrm{CFU} / \mathrm{mL}$ ). After inoculation, each test tube was mixed using a vortex mixer (Sybron Maxi Mix model M-16715, Thermolyne Corporation, Dubuque Iowa, USA) for 10 seconds. Prior to applying the TTC-test, 


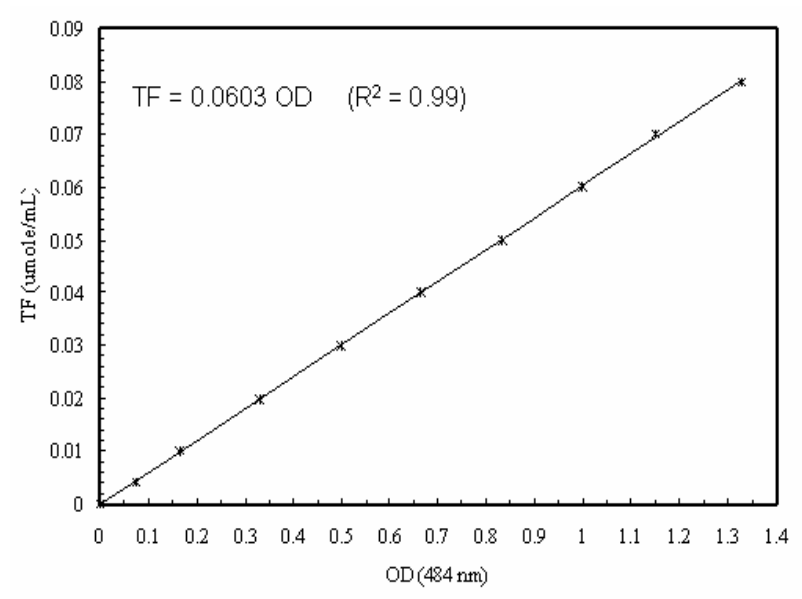

Fig.1: Triphenyl formazan standard curve.

the prepared samples were incubated (stationary) for 60 $\mathrm{h}$ at room temperature $\left(24{ }^{\circ} \mathrm{C}\right)$ in order to allow for spores germination. After the incubation period, a mat of white mycelia was formed on the surface of the broth in the test tubes.

\section{Dehydrogenase Activity Measurement.}

Each sample was transferred to a $50 \mathrm{~mL}$ centrifuge tube with a screw cap. An amount of $2.5 \mathrm{~mL}$ of the tris buffer solution was added to each tube and the $\mathrm{pH}$ was adjusted to the desired value using either $1 \mathrm{~N}$ sodium hydroxide or $1 \mathrm{~N}$ hydrochloric acid. An aliquot of 0.5 $\mathrm{mL}$ of TTC/glucose solution (having the desired concentration) was transferred to each tube. For the control tubes, samples were autoclaved in an autoclave (Model No. STM-E, Market Forge Sterilmatic, New York) three times (45 minutes each in three consecutive days at $121{ }^{\circ} \mathrm{C}$ and $103.4 \mathrm{kPa}$ ). The contents of the tubes were mixed using a vortex mixer (Sybron Maxi Mix model M-16715, Thermolyne Corporation, Dubuque Iowa, USA) for 30 seconds and then incubated at the desired temperature for the assigned incubation time. The tubes were centrifuged after the incubation period at $2150 \mathrm{rpm}(975 \times \mathrm{g})$ for 20 minutes in order to separate the fungal cells from the liquid media. The supernatant was discarded and 2.5 $\mathrm{mL}$ ethyl alcohol was added to the remained fungal cells. The tubes were shaken using the vortex mixer and then centrifuged at $2150 \mathrm{rpm}(975 \times \mathrm{g})$ for 20 minutes. The suspension was transferred to a test tube. One more extraction of the retained fungal cells with 2.5 $\mathrm{mL}$ ethyl alcohol was done (further extraction did not provide any red color). The supernatant was transferred to the test tube and the combined suspension was shaken. Finally, the optical density of the combined suspension was measured at $484 \mathrm{~nm}$ using a spectrophotometer (Spectronic 160, Fisher Scientific Montreal, Quebec, Canada). The control sample was used to zero the spectrophotometer. The formazan concentration was then obtained from the standard curve.

\section{RESULTS AND DISCUSSION}

\section{Triphenyl Formazanyield}

An attempt to use TT-C test for assessing the viability of A.niger spores was unsuccessful. Since other organic salts were used to assess the viability of fungal spores $^{[21-27]}$ and the TTC has the ability to penetrate A.niger spores based on its molecular weight ${ }^{[28]}$, either the ethanol was not effective in extracting enough TF (to cause red color) or the ethanol extracted significant amount of black color from the spore which interfered with the measurement.

Table 1 show triphenyl formazan yield and TTC consumption resulting from the dehydrogenase activity of $A$. niger vegetative cells under various TTC concentrations, $\mathrm{pH}$ values, temperatures and incubation times. The values are the average of two replicates. The coefficient of variation ranged from 0.2 to $18.7 \%$. Analysis of variance was performed on the formazan concentration $(\mu \mathrm{g} / \mathrm{mL})$ using SAS System (5th Ed, SAS Institute Inc., Cary, North Carolina) as shown in Table 2. The Duncan's Multiple Range test was also performed on the data to test the differences among the levels of each parameter as shown in Table 3. The analysis showed that the TTC concentration, $\mathrm{pH}$, temperature and incubation time all had significant effects on the formazan concentration ( $P$ $=0.0001)$. There were also significant interactions between the parameters $(\mathrm{P}=0.0001)$. Figure 2 shows the interaction between these parameters. The levels of each of the four parameters (TTC concentration, $\mathrm{pH}$, temperatures and incubation period) were significantly different from one another at $95 \%$ confidence. The effects of TTC concentration, $\mathrm{pH}$, temperature and incubation time on TF yield can be described by the following equation $\left(\mathrm{R}^{2}=0.92\right)$ :

$T F=1.9177 \times 10^{-4} e^{\left(0.0973 T T C+0.679 p H+0.168 T-0.0014 T^{2}+0.297 t\right)}$

Where:

$\begin{array}{ll}\text { TTC } & \text { is the TTC concentration }(\mathrm{g} / \mathrm{L}) \\ \mathrm{pH} & \text { is the medium } \mathrm{pH} \\ \mathrm{TF} & \text { is the TF yield }(\mu \mathrm{g}) \\ \mathrm{T} & \text { is the incubation temperature }\left({ }^{\circ} \mathrm{C}\right) \\ \mathrm{t} & \text { is the incubation time }(\mathrm{h})\end{array}$

\section{Sensitivity Analyses}

To test the sensitivity of the model to each parameter, the values of the tested parameters were varied within the range studied whereas the values of the other parameters were kept at their respective base values (optimum results) as shown in Table 4. The results of the sensitivity analysis (Figure 3) showed that the TF yield was more sensitive to changes in temperature 
Table 1. Effects of temperature, $\mathrm{pH}$ and TTC concentration on formazan formation during the $1.5 \mathrm{~h}$ incubation period.

\begin{tabular}{|c|c|c|c|c|c|c|}
\hline \multirow{2}{*}{$\begin{array}{c}\text { Temperature } \\
\left({ }^{\circ} \mathrm{C}\right)\end{array}$} & \multirow[t]{2}{*}{$\mathrm{pH}$} & \multirow{2}{*}{$\begin{array}{l}\text { TTC } \\
(\mathrm{g} / \mathrm{L})\end{array}$} & \multirow{2}{*}{$\begin{array}{c}\text { TTC Added }^{\mathrm{a}} \\
(\mu \mathrm{g})\end{array}$} & \multicolumn{3}{|c|}{ TF Produced $^{b}(\mu \mathrm{g})$} \\
\hline & & & & $1.5 \mathrm{~h}$ & $3.0 \mathrm{~h}$ & $4.5 \mathrm{~h}$ \\
\hline \multirow[t]{9}{*}{25} & 7 & 5 & 2243.99 & 1.36 & 2.35 & 3.31 \\
\hline & & 10 & 4487.98 & 2.04 & 4.62 & 6.16 \\
\hline & & 15 & 6728.96 & 4.03 & 6.39 & 7.88 \\
\hline & 8 & 5 & 2243.99 & 3.71 & 6.11 & 7.52 \\
\hline & & 10 & 4487.98 & 5.84 & 8.24 & 13.86 \\
\hline & & 15 & 6728.96 & 7.47 & 12.95 & 17.34 \\
\hline & 9 & 5 & 2243.99 & 5.75 & 9.24 & 14.22 \\
\hline & & 10 & 4487.98 & 6.52 & 20.20 & 15.90 \\
\hline & & 15 & 6728.96 & 8.11 & 25.68 & 43.88 \\
\hline \multirow[t]{9}{*}{40} & 7 & 5 & 2243.99 & 2.81 & 7.02 & 11.28 \\
\hline & & 10 & 4487.98 & 4.85 & 10.55 & 17.34 \\
\hline & & 15 & 6728.96 & 8.74 & 24.86 & 22.96 \\
\hline & 8 & 5 & 2243.99 & 5.57 & 11.73 & 22.98 \\
\hline & & 10 & 4487.98 & 17.07 & 20.24 & 35.91 \\
\hline & & 15 & 6728.96 & 24.45 & 33.78 & 69.42 \\
\hline & 9 & 5 & 2243.99 & 15.22 & 29.53 & 60.64 \\
\hline & & 10 & 4487.98 & 23.87 & 44.06 & 70.87 \\
\hline & & 15 & 6728.96 & 42.84 & 77.30 & 129.20 \\
\hline \multirow[t]{9}{*}{55} & 7 & 5 & 2243.99 & 4.94 & 9.42 & 11.73 \\
\hline & & 10 & 4487.98 & 12.63 & 21.92 & 28.21 \\
\hline & & 15 & 6728.96 & 17.30 & 36.91 & 31.20 \\
\hline & 8 & 5 & 2243.99 & 15.53 & 22.28 & 37.04 \\
\hline & & 10 & 4487.98 & 37.45 & 25.63 & 31.79 \\
\hline & & 15 & 6728.96 & 52.30 & 45.06 & 59.32 \\
\hline & 9 & 5 & 2243.99 & 36.27 & 28.89 & 45.96 \\
\hline & & 10 & 4487.98 & 44.02 & 49.81 & 89.66 \\
\hline & & 15 & 6728.96 & 84.68 & 84.28 & 136.85 \\
\hline
\end{tabular}

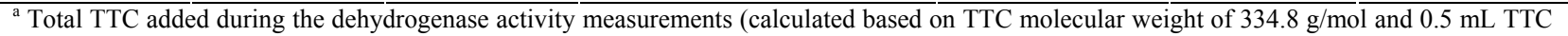
glucose solution added to each sample)

${ }^{\mathrm{b}}$ Total amount of TF extracted (calculated based on TF molecular weight of $300.4 \mathrm{~g} / \mathrm{mol}$ and the usage of $5 \mathrm{~mL}$ alcohol for extraction)

Table 2. Analysis of variance.

\begin{tabular}{|c|c|c|c|c|c|}
\hline Source & DF & SS & MS & F-Value & $\mathrm{P}$ \\
\hline Total & 161 & 4787.8683 & & & \\
\hline Model & 80 & 4762.5219 & 59.5315 & 190.25 & 0.0001 \\
\hline TTC & 2 & 699.6380 & 349.8190 & 1117.92 & 0.0001 \\
\hline $\mathrm{pH}$ & 2 & 1286.8033 & 643.4016 & 2056.13 & 0.0001 \\
\hline $\mathrm{T}$ & 2 & 1076.2404 & 538.1202 & 1719.68 & 0.0001 \\
\hline $\mathrm{t}$ & 2 & 472.0135 & 236.0068 & 754.21 & 0.0001 \\
\hline $\mathrm{TTC} * \mathrm{pH}$ & 4 & 204.5133 & 51.1283 & 163.39 & 0.0001 \\
\hline $\mathrm{TTC} * \mathrm{~T}$ & 4 & 160.2992 & 40.0748 & 128.07 & 0.0001 \\
\hline $\mathrm{TTC} * \mathrm{t}$ & 4 & 48.1151 & 12.0288 & 38.44 & 0.0001 \\
\hline $\mathrm{pH}^{*} \mathrm{~T}$ & 4 & 267.7266 & 66.9316 & 213.89 & 0.0001 \\
\hline $\mathrm{pH}^{*} \mathrm{t}$ & 4 & 195.1633 & 48.7908 & 155.92 & 0.0001 \\
\hline $\mathrm{T} * \mathrm{t}$ & 4 & 122.7424 & 30.6856 & 98.06 & 0.0001 \\
\hline $\mathrm{TTC}^{*} \mathrm{pH} * \mathrm{~T}$ & 8 & 47.4259 & 5.9282 & 18.95 & 0.0001 \\
\hline $\mathrm{TTC}^{*} \mathrm{pH} * \mathrm{t}$ & 8 & 61.8320 & 7.7290 & 24.70 & 0.0001 \\
\hline $\mathrm{TTC} * \mathrm{~T} * \mathrm{t}$ & 8 & 11.4468 & 1.4309 & 4.57 & 0.0001 \\
\hline $\mathrm{pH} * \mathrm{~T}_{\mathrm{I}} * \mathrm{t}$ & 8 & 71.8236 & 8.9779 & 28.69 & 0.0001 \\
\hline $\mathrm{TTC}^{*} \mathrm{pH} * \mathrm{~T} * \mathrm{t}$ & 16 & 36.7385 & 2.2962 & 7.34 & 0.0001 \\
\hline Error & 81 & 25.3464 & 0.3129 & & \\
\hline
\end{tabular}

$\begin{array}{ll}\mathrm{R}^{2} & =0.99 \\ \mathrm{CV} & =10.19 \%\end{array}$

followed by $\mathrm{pH}$, TTC concentration and incubation time.

\section{Effect of TTC Concentration}

The TF yield from the vegetative cells increased when the TTC concentration was increased from 5 to $15 \mathrm{~g} / \mathrm{L}$. Increasing the TTC concentration by 2.5 units $(\mathrm{g} / \mathrm{L})$ increased the TF yield by $27.53 \%$. The direct relationship between TTC concentration and TF yield 
Table 3. Differences among the levels of the TTC concentration, $\mathrm{pH}$, temperature and incubation time.

\begin{tabular}{lccc}
\hline Parameter & $\begin{array}{c}\text { No. of } \\
\text { Observations }\end{array}$ & $\begin{array}{c}\text { TF Concentration } \\
(\mu \mathrm{g} / \mathrm{mL})\end{array}$ & $\begin{array}{c}\text { Duncan } \\
\text { Grouping }\end{array}$ \\
\hline $\begin{array}{c}\text { TTC Concentration }(\mathrm{g} / \mathrm{L}) \\
15\end{array}$ & 54 & 8.26 & $\mathrm{~A}$ \\
10 & 54 & 4.96 & $\mathrm{~B}$ \\
5 & 54 & 3.25 & $\mathrm{C}$ \\
\hline $\mathrm{pH}$ & & & \\
9 & 54 & 9.21 & $\mathrm{~A}$ \\
8 & 54 & 4.87 & $\mathrm{~B}$ \\
7 & 54 & 2.39 & $\mathrm{C}$ \\
\hline Temperature $\left({ }^{\circ} \mathrm{C}\right)$ & & & \\
55 & 54 & 8.16 & $\mathrm{~A}$ \\
40 & 54 & 6.31 & $\mathrm{~B}$ \\
25 & 54 & 2.00 & $\mathrm{C}$ \\
\hline Incubation Time (h) & & & \\
4.5 & 54 & 7.77 & $\mathrm{~A}$ \\
3 & 54 & 5.03 & $\mathrm{~B}$ \\
1.5 & 54 & 3.67 & $\mathrm{C}$ \\
\hline & \\
* Means with the same letter are not significantly different from each \\
other at 95\% confidence level. & &
\end{tabular}

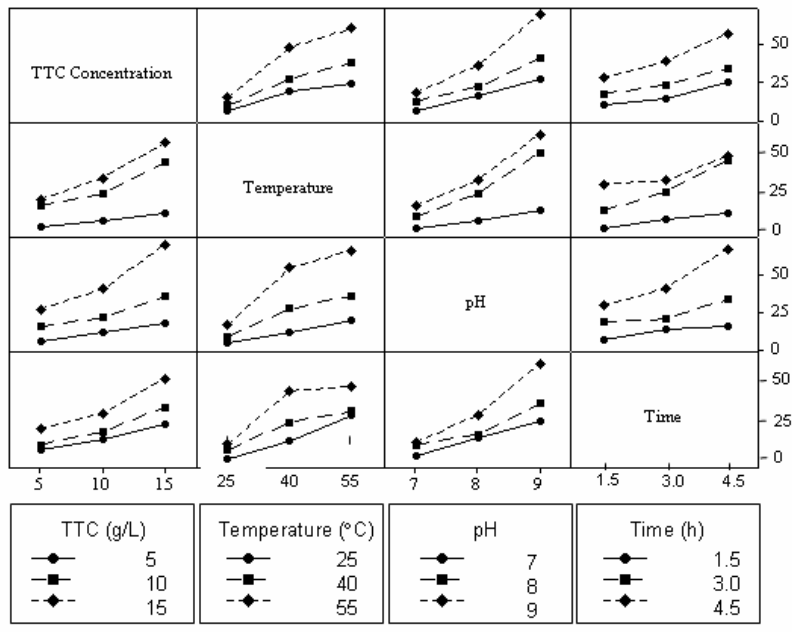

Fig. 2: Interaction plots for the TTC concentration, $\mathrm{pH}$, temperature and incubation time.

can be described by the following exponential equation $\left(\mathrm{R}^{2}=0.99\right)$ :

$$
T F=24.09 e^{0.10 T T C} \quad(5 \leq \mathrm{TTC} \leq 15 \mathrm{mg} / \mathrm{L})
$$

A very small percentage $(0.05-2.70 \%)$ of the added TTC was reduced to triphenyl formazan.

Tetrazolium salts vary in their ability to penetrate through intact cell plasma membrane ${ }^{[28,29]}$. Altman ${ }^{[28]}$ reported that intact cells and subcellular membranes can constitute barriers to the entry of tetrazolium salts. A low concentration of the salt at the enzymatic reaction site may, therefore, be a rate limiting factor even if the concentration in the medium is sufficient.

Bernas and Dobrucki ${ }^{[29]}$ provided evidence suggesting that MTT (3-(4,5-dimethyl-2-thiazolyl)- 2,5-diphenyl-
Table 4. Base values and range of parameters used for the sensitivity analysis.

\begin{tabular}{|c|c|c|c|}
\hline Variable & Level & Base & Range \\
\hline \multirow[t]{5}{*}{ TTC Concentration $(\mathrm{g} / \mathrm{L})$} & 5 & 15 & 5.0 \\
\hline & & & 7.5 \\
\hline & & & 10.0 \\
\hline & & & 12.5 \\
\hline & & & 15.0 \\
\hline \multirow[t]{5}{*}{$\mathrm{pH}$} & 5 & 9 & 7.0 \\
\hline & & & 7.5 \\
\hline & & & 8.0 \\
\hline & & & 8.5 \\
\hline & & & 9.0 \\
\hline \multirow[t]{7}{*}{ Temperature $\left({ }^{\circ} \mathrm{C}\right)$} & 7 & 55 & 25 \\
\hline & & & 30 \\
\hline & & & 35 \\
\hline & & & 40 \\
\hline & & & 45 \\
\hline & & & 50 \\
\hline & & & 55 \\
\hline \multirow[t]{7}{*}{ Incubation Time (h) } & 7 & 3 & 1.5 \\
\hline & & & 2.0 \\
\hline & & & 2.5 \\
\hline & & & 3.0 \\
\hline & & & 3.5 \\
\hline & & & 4.0 \\
\hline & & & 4.5 \\
\hline
\end{tabular}
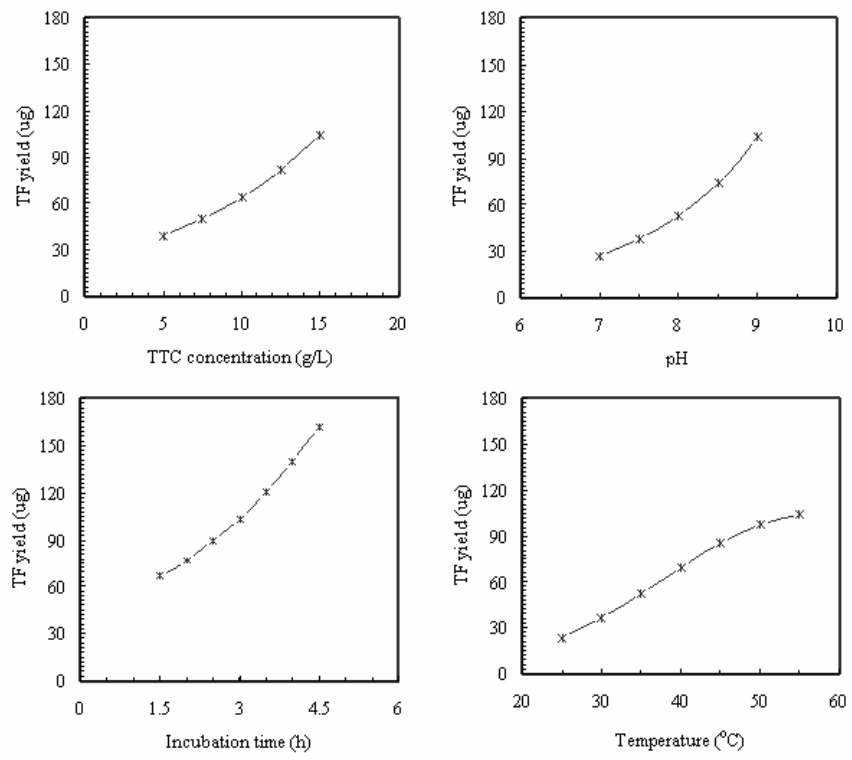

Fig.3: Relative effects of TTC concentration, $\mathrm{pH}$, temperature and incubation time on TF yield.

2H-tetrazolium bromide) can readily penetrate intact plasma membranes while CTC (5-cyano-2,3- ditolyl tetrazolium chloride) remains extracellular and requires membrane permeable electron carrier to be reduced efficiently. Altman ${ }^{[28]}$ stated that MTT is able to 
penetrate mitochondrial membrane more readily than NT (3,3'-(4,4'-biphenylylene)-bis-(2,5-diphenyl-2Htetrazolium chloride)) because it has a smaller molecular weight (414 g vs. $668 \mathrm{~g}$ ). Based on this explanation, it appears that the ability of TTC to penetrate cell membranes would be relatively higher since it has the smallest molecular weight $(335 \mathrm{~g})$ among the common tetrazolium salts.

However, Altman ${ }^{[28]}$ and Altman ${ }^{[30]}$ rated TTC as having the lowest reducibility among tetrazolium salts and found the activity of TTC to be affected by the presence of $\mathrm{O}_{2}$. One electron reduction of TTC produces a TTC free radical, which under anaerobic conditions could be further reduced by the addition of another electron to TF. In the presence of $\mathrm{O}_{2}$, the TTC radical reduces $\mathrm{O}_{2}$ to superoxide $\left(\mathrm{O}_{2}\right)$ and itself becomes oxidized back to TTC. According to Bernas \& Dobrucki $^{[29]}$, the molecular structure of tetrazolium salts as well as the presence of electron carrier strongly influence the rates and the ability to penetrate through cellular membranes.

Since other organic salts were used to assess the viability of fungus spores and the TTC has the ability to penetrate A. niger spores (based on its small molecular weight), either the ethanol was not effective in extracting enough TF (to cause red color), the exhaust or extracted significant amount of the black color of the spores, that interfered with red color measurement.

\section{Effect of pH}

The TF yield increased with increases in $\mathrm{pH}$ within the studied range $(7-9 \mathrm{~g} / \mathrm{L})$. Increasing the $\mathrm{pH}$ by one unit, increased the $\mathrm{TF}$ yield by $40.42 \%$. The direct relationship between $\mathrm{pH}$ and $\mathrm{TF}$ yield can be described by the following exponential equation $\left(\mathrm{R}^{2}=\right.$ $0.99)$.

$$
T F=0.23 e^{0.68 p H} \quad(7 \leq \mathrm{pH} \leq 9)
$$

Ghaly and Ben-Hassan ${ }^{[14]}$ reported an optimum $\mathrm{pH}$ range of $7.0 \pm 0.2$ for measuring the dehydrogenase activity of Kluyveromyces fragilis and Candida pseudotropicalis using TTC. They stated that a $\mathrm{pH}$ change of 3 units was able to hinder the enzymatic activity. Shuler and Kargi ${ }^{[31]}$ reported that $\mathrm{pH}$ may affect enzymes in three ways: (a) changes in the medium $\mathrm{pH}$ result in changes in the ionic form of the active sites of the enzymes, which in turn affect the activity of the enzyme and hence the reaction rate, (b) variations in $\mathrm{pH}$ may alter the three-dimensional shape of the enzyme and (c) sometimes the substrate contain ionic groups and hence the affinity of the substrate to the enzyme is affected by changes in the $\mathrm{pH}$. Mahmoud and Ghaly ${ }^{[18]}$ reported no reductions in TTC under acidic conditions $(<6.5)$ and found chemical reduction of TTC at $\mathrm{pH}$ of 9.5. The results obtained from this study indicated that a $\mathrm{pH}$ of 9 appeared to be the optimum for measuring the dehydrogenase activity of A. niger.

\section{Effect of Incubation Time}

The TF yield increased with increases in incubation time within the studied range $(1.5-4.5 \mathrm{~h})$. Increasing the incubation time by one hour, increased the TF yield by $32.00 \%$. The direct relationship between incubation time and TF yield can be described by the following exponential equation $\left(R^{2}=0.99\right)$ :

$$
T F=42.53 e^{0.3 t} \quad\left(1.5 \leq \mathrm{t}_{\mathrm{I}} \leq 4.5 \mathrm{~h}\right)
$$

Ghaly and Ben-Hassan ${ }^{[14]}$ reported an optimum incubation time of $80 \mathrm{~min}$ for measuring the dehydrogenase activity of Kluyveromyces fragilis and Candida pseudotropicalis using TTC of $5 \mathrm{~g} / \mathrm{L}$ concentration at a $\mathrm{pH}$ of 7 and a temperature of $20{ }^{\circ} \mathrm{C}$. $\operatorname{Ross}^{[32]}$ reported a gradual decrease in formazan formation after an incubation time of $1 \mathrm{~h}$. Griebe et al. ${ }^{[(33]}$ reported a decrease in the rate of formazan formation after $2 \mathrm{~h}$ incubation time when CTC was incubated with activated sludge and stated that no significant increase was realized in formazan formation after $4 \mathrm{~h}$ incubation time. Although, the TF yield increased exponentially with time in this study, an incubation time greater that $4 \mathrm{~h}$ would be considered very lengthy and impractical.

\section{Effect of Temperature}

The TF yield increased with increases in temperature within the studied range $\left(25-55^{\circ} \mathrm{C}\right)$. The relationship between TF yield and incubation temperature can be described by the following Arrhenius equation $\left(\mathrm{R}^{2}=\right.$ $0.93)$ :

$$
T F=297 \times 10^{6} e^{-40,098 / R T} \quad\left(25^{\circ} \mathrm{C} \leq \mathrm{T} \leq 55^{\circ} \mathrm{C}\right)
$$

Where:

$$
T \text { is the absolute temperature }(\mathrm{K})
$$

Trevors $^{[34]}$ observed significant increase in dehydrogenase activity with increases in the incubation temperature up to $50{ }^{\circ} \mathrm{C}$. Trevors ${ }^{[35]}$ observed a high positive linear correlation between incubation temperature (in the range of 5 to $70{ }^{\circ} \mathrm{C}$ ) and the color development when measuring dehydrogenase activity in soils using INT. Wiseman ${ }^{[36]}$ stated that chemical reaction rates increase with rises in temperature by a factor of between 0 and 1 with each $10{ }^{\circ} \mathrm{C}$ rise in temperature. Doran ${ }^{[37]}$ reported that for enzyme reactions, a $10{ }^{\circ} \mathrm{C}$ rise in temperature between 20 and $30{ }^{\circ} \mathrm{C}$ increases the rate of reaction by a factor of 2-3. Although the results obtained from these experiments showed that the TF yield increased with the increase in temperature, the amount of increase in TF yield for 


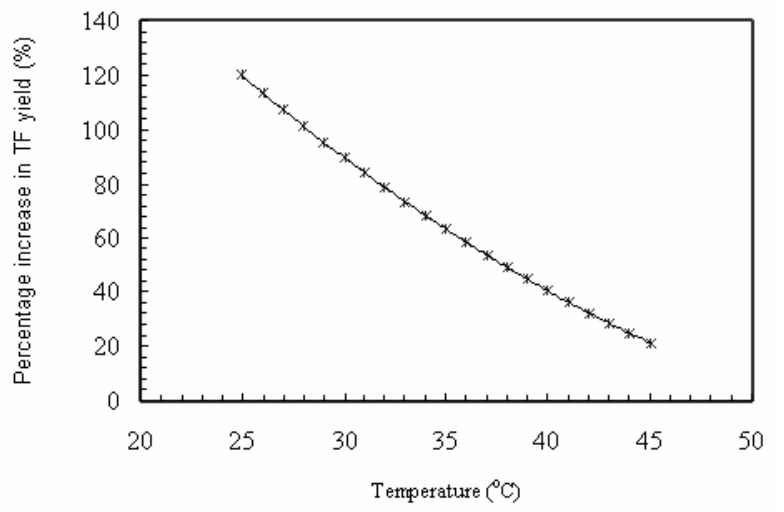

Fig. 4: Effect of temperature on Enzyme activity.

every $10{ }^{\circ} \mathrm{C}$ increase in the temperature declined gradually as shown in Figure 4.

$\operatorname{Doran}^{[37]}$ stated that the kinetics of most enzymatic reactions can be sufficiently represented by MichaelisMenten equation.

$$
v=\frac{v_{\max } C}{K_{m}+C}
$$

Where:

$$
\begin{aligned}
& C \text { is the concentration of the substrate } \\
& (\mu \mathrm{mol} / \mathrm{mL}) \\
& K_{m} \quad \text { is the Michaelis-Menten constant and is }
\end{aligned}
$$

Bu'lock and Kristiansen ${ }^{[38]}$ and Shuler and Kargi $\left.{ }^{[31}\right]$ indicated that the temperature affects the conformation of enzymes and very rapid changes in the activities can take place over a small temperature range as variations in temperature affects both $U_{\max }$ and $\mathrm{K}_{\mathrm{m}}$. However, the rate of an enzymatic reaction increases with the increase in temperature up to a certain limit above which enzyme activity decreases as a result of thermal deactivation (or enzyme denaturation) as shown in Figure $5^{[35,36]}$. The ascending part of the curve describes the activation effect of temperature on enzyme while the descending part describes the deactivation effect of temperature on enzyme. The rate of enzyme activation and deactivation can be described by the following Arrhenius equations ${ }^{[38]}$.

$$
\begin{aligned}
& \mathrm{k}_{\mathrm{a}}=\mathrm{A}_{\mathrm{a}} \mathrm{e}^{-\frac{\mathrm{E}_{\mathrm{a}}}{\mathrm{RT}}} \\
& \mathrm{k}_{\mathrm{d}}=\mathrm{A}_{\mathrm{d}} \mathrm{e}^{-\frac{\mathrm{E}_{\mathrm{d}}}{\mathrm{RT}}}
\end{aligned}
$$

Where:

$\begin{array}{ll}A_{a} & \text { is the Arrhenius constant for enzyme } \\ & \text { activation }\left(\mathrm{h}^{-1}\right) \\ A_{d} & \text { is the Arrhenius constant for enzyme } \\ & \text { deactivation }\left(\mathrm{h}^{-1}\right) \\ E_{a} & \text { is the activation Energy }(\mathrm{J} / \mathrm{mol}) \\ E_{d} & \text { is the deactivation Energy }(\mathrm{J} / \mathrm{mol}) \\ k_{\mathrm{a}} & \text { is the activation rate constant }\left(\mathrm{h}^{-1}\right) \\ k_{d} & \text { is the deactivation rate constant }\left(\mathrm{h}^{-1}\right) \\ R & \text { is the gas constant }(8.314 \mathrm{~J} / \mathrm{mol} . \mathrm{K})\end{array}$

The overall maximum rate of reaction $v_{\max }$ can, therefore, be expressed as follows (38).

$\mathrm{v}_{\max }=\mathrm{A}_{\mathrm{a}} \mathrm{e}^{-\mathrm{E}_{\mathrm{a}} / \mathrm{RT}}-\mathrm{A}_{\mathrm{d}} \mathrm{e}^{-\mathrm{E}_{\mathrm{d}} / \mathrm{RT}}$
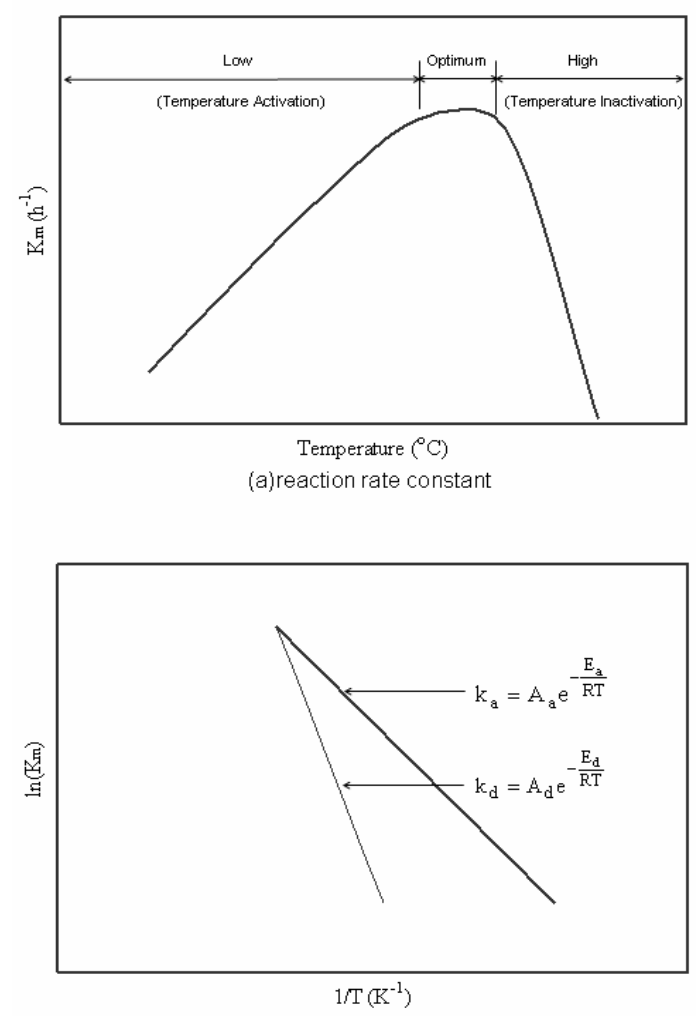

(b) Activation and deactivation rate constants

Fig. 5: Percent increase in the amount of TF produced for every $10{ }^{\circ} \mathrm{C}$ increase in temperature.

In equation [11], the first term accounts for the general increase in the reaction rate with temperature while the 
second term, which has much higher activation energy than the first term, is associated with the rapid reduction in the activity of the enzyme as the temperature increases beyond the optimum. There is a linear relationship between the logarithm of the reaction rate constant and the inverse of the absolute temperature as shown in Figure $4^{[38]}$. The activation energy for the TTC biochemical chemical reduction for A. niger vegetative cells in the temperature range from 25 to 55 ${ }^{\circ} \mathrm{C}$ was estimated to be $40,098 \mathrm{~J} / \mathrm{mol}$. This is within the ranges of $16,736-83,680 \mathrm{~J} / \mathrm{mol}$ reported by Wiseman ${ }^{[36]}$ and Shuler and Kargi ${ }^{[31]}$ and of 40,000-80,000 J/mol reported by Doran ${ }^{[37]}$ for enzyme catalyzed reactions.

Doran $^{[37]}$ reported that the deactivation energy for many enzymes is in the order $170,000-400,000 \mathrm{~J} / \mathrm{mol}$, which means that for every $10{ }^{\circ} \mathrm{C}$ rise in temperature between 30 to $40{ }^{\circ} \mathrm{C}$, the rate of enzymatic deactivation increases by a factor between 10 and 150 . Shuler and Kargi ${ }^{[31]}$ reported that a rise in temperature from 30 to $40{ }^{\circ} \mathrm{C}$ resulted in a 41 fold increase in enzyme denaturation. Hecht et al. ${ }^{[39]}$ stated that, under certain conditions, enzyme denaturation only occurs at temperatures higher than $55^{\circ} \mathrm{C}$. Although the enzyme activity decreased gradually with the increase in temperature in this study, complete enzyme denaturation was not realized below $55{ }^{\circ} \mathrm{C}$.

\section{CONCLUSIONS}

An attempt to use TTC-test for assessing the viability of A. niger spores was unsuccessful. Since other organic salts were used to assess the viability of fungal spores and the TTC has the ability to penetrate A.niger spores (based on its molecular weight), either the ethanol was not effective in extracting enough TF (to cause red color) or the ethanol extracted significant amount of black color from the spore which interfered with the measurement of the red color. TTC-test can effectively be used for dehydrogenase activity measurements of $A$. niger vegetative cells. The TF yield increased with increases in TTC concentration (from 5 to $15 \mathrm{~g} / \mathrm{L}$ ), $\mathrm{pH}$ (from 7 to 9), temperature (from 25 to $55{ }^{\circ} \mathrm{C}$ ) and incubation time (from 1.5 to $4.5 \mathrm{~h}$ ). The TF yield was more sensitive to changes in temperature followed by $\mathrm{pH}$, TTC concentration and incubation time. The optimum TTC-test conditions for measuring the dehydrogenase activity of $A$. niger vegetative cells are a TTC concentration of $15 \mathrm{~g} / \mathrm{L}$, a $\mathrm{pH}$ of 9 , a temperature of $55^{\circ} \mathrm{C}$ and an incubation time of $4 \mathrm{~h}$. Measuring the dehydrogenase activity using TTC-test is simple, fast, cheap and can be applied for biomass quantification during liquid and solid-state fermentation. Although the procedure has been successfully tested with mycelia of different stages of growth, it would be interesting to test the effects of different stages of growth on TTC reduction under both aerobic and anaerobic conditions.

\section{ACKNOWLEDGMENT}

This research was funded by the National Science and Engineering Council of Canada (NSERC). The financial support provided by Dalhousie University Killam Scholarship is highly appreciated.

\section{REFERENCES}

1. Berka RM, Dunn-Coleman N, Ward M (1992) Industrial enzymes from Aspergillus species. In Aspergillus Biology and Industrial Applications, Bennett JW, Klich MA, Ed.; Butterworth-Heinemann, Stoneham, MA, USA

2. Ray B (1996) Fundamental Food Microbiology. CRC Press, Florida, USA

3. Naidu GSN, Panda T (2003) Studies on pH and thermal deactivation of pectolytic enzymes from Aspergillus niger. Biochemical Engineering Journal 16: 57-67

4. Pandey A (1992) Recent process developments in solid-state fermentation. Process Biochemistry 27:109-117

5. Stagg C M, Feather M S (1973) The Characterization of a chitin-associated Dglucan from the cell walls of Aspergillus niger. International Journal of Biochemistry, Biophysics and Molecular Biology 320: 64-72

6. Brzeski M M (1987) Chitin and chitosan putting waste to good use. INFOFISH International 5: 38-40

7. Hesseltine C W (1977) Solid state fermentaton. Part I. Process Biochemistry12: 24-27

8. Durand A, Broise D, Blachere H (1988) Laboratory scale bioreactor for solid state process. Journal of Biotechnology 8: 59-66

9. Ruhling A, Tyler G (1973) Heavy metal pollution and decomposition of spurce needle litter. Oikos 24: 402-416

10. Rogers J E, Li S W (1985) Effect of metals and other inorganic ions on soil microbial activity: Soil dehydrogenase assay as a simple toxicity test. Bulletin of Environmental Contamination and Toxicology 34: 858-865

11. Chander K, Brookes P C (1991) Is the dehydrogenase assay invalid as a method to estimate microbial activity in coppercontaminated soils? Soil Biology and Biochemistry 23 : 909-915

12. Tengerdy R P, Nagy J G, Martin B (1967) Quantitative measurement of bacterial growth by the reduction of tetrazolium salts. Applied Microbiology 15: 954-955 
13. Skujiņš J (1973) Dehydrogenase: An indicator of biological activities in arid soils. Bull. Ecol. Res. Comm., Stockholm 17: 235-241

14. Ghaly A E, Ben-Hassan R M (1993) Dehydrogenase activity measurment in yeast fermentation. Applied Biochemistry and Biotechnology 4: 77-92

15. Ohara M T, Saito T (1995) Application of triphenyltetrazolium chloride in microbial limit test of pharmaceuticals and cosmetics. Journal of AOAC International 78: 1525-1529

16. Gabrielson J, Hart M, Jarelov A, Kuhn I, McKenzie D,Mollby R (2002) Evaluation of redox indicators and the use of digital scanners and spectrophotometer for quantification of microbial growth in microplates. Journal of Microbiological Methods 50: 63-73

17. Lenhard G, Nourse L D, Schwartz HM (1964) The measurement of dehydrogenase activity of activated sludges. Advances in water pollution research. In Proceeding of the $2^{\text {nd }}$ International Conference; Baars, J.K., Ed.; Pergamon Press, Tokyo 2: 105-119

18. Mahmoud N S, Ghaly A E (2004) Influence of temperature and $\mathrm{pH}$ on the non-enzymatic reduction of triphenyltetrazolium chloride. Biotechnology Progress 20: 346-353

19. Messer J W, Behney H M, Leudecke L O (1985) Microbiological count methods. In Standard Methods for the Examination of Dairy Products, $15^{\text {th }}$ ed., Richardson, G.H. Ed.; American Public Health Assosiation, Washington D.C

20. Klein D A, Loh T C, al Goulding R L (1971) A rapid procedure to evaluate the dehydrogenase activity in soil low in organic matter. Soil Biology and Biochemisitry 3:385-387

21. Sutherland E D, Cohen S D (1983) Evaluation of tetrazolium bromide as a vital stain for fungi oospores. Phytopathology 73: 1532-1535

22. El-Hamalawi Z A, Erwin D C (1986) Physical, enzymatic and chemical factors affecting viability and germnonation of oospores of Phytophthora megasperma f.sp. medicaginis.Physiology and Biochemisry76: 503-507

23. An Z-Q, Hendrix J W (1988) Determining viability of endogonaceous spores with a vital stain.Mycologia 80: 259-261

24. Jiang J, Erwin D C (1990) Morphology, plasmolysis and tetrazolium bromidestain as criteria for determining viability of Phytophthora oospores. Mycologia 82: 107-113

25. Meier R, Charvat I (1993) Reassesment of tetrazolium bromide as a vitality stain for spores of vesicular-arbuscular mycorrhizal fungi. American Journal of Botany 80: 10071015
26. Walley F L, Germida J J (1995) Estimating the viability of vesicular-arbuscular mycorrhizae fungal spores using tetrazolium salts as vital stain. Mycologia 87: 273-279

27. Stentelaire C, Antoine N, Cabrol, C, Feron, Durand A (2001) Development of a rapid and highly sensitive biochemical method for the measurement of fungal spore viability. An alternative to the CFU method. Enzyme and Microbial Technology 29: 560-566

28. Altman F P (1976) Tetrazolium salts and formazans. Progress in Histochemistry and Cytochemistry 9:1-56

29. Bernas T, Dobrucki J W (2000) The role of plasma membrane in bioreduction of two tetrazolium salts, MTT and CTC. Archives of Biochemistry and Biophysics 380: 108-116.

30. Altman F P (1969) The use of eight different tetrazolium salts for a quantitative study of pentose shunt dehydrogenation. Histochemie 19: 363-374

31. Shuler M L, Kargi F (1992) Bioprocess Engineering Basic Concepts. Prentice-Hall, Inc., Englewood Cliffs, New Jersey

32. Ross D J (1971) Some factors influencing the estimation of dehydrogenase activities of some soils under pasture. Soil Biology and Biochemistry 3: 97-110.

33. Griebe T, Schaule G, Wuertz S (1997) Determination of microbial respiratory and redox activity in activated sludge. Journal of Industrial Microbiology and Biotechnology 19: $118-122$

34. Trevors J T (1984) Dehydrogenase activity in soil: a comparison between the INT and TTC assay. Soil biology and Biochemistry 16: 673674

35. Trevors J T (1984) Effect of substrate concentration, inorganic nitrogen, $\mathrm{O}_{2}$ concentration, temperature and $\mathrm{pH}$ on dehydrogenase activity in soil. Plant and Soil 77: 285-293

36. Wiseman A (1985) Handbook of Enzyme Biotechnology. Ellis Hardwood Limited, London, England

37. Doran P M (1995) Bioprocess Engineering Principles. Academic Press Limited, London. UK

38. Bu'lock J, Kristiansen B (1987) Basic Biotechnology. Academic Press, INC. San Diego, CA 92101

39. Hecht $\mathrm{K}$, Langer $\mathrm{T}$, Wrba A, Jaenicke $\mathrm{R}$ Lactate (1990) dehydrogenase from the extreme halophilic archaebacterium Halobacterium marismortui. Biological Chemistry Hoppe-Seyler371: 515-519 